\title{
Félmerev keretcsomópont nyomaték-szögelfordulás karakterisztikájának meghatározása az EUROCODE 3 alapján
}

\author{
Csiky Vidor
}

\begin{abstract}
Steel frames are commonly used in engineering practice for the structure of frameworks, buildings and carcases. The calculation of the rotational stiffness of an extended end-plate frame node is presented according to Eurocode 3. By means of the rotational stiffnesses the moment-rotational characteristics of the connection is deternined using the Curve Expert software.
\end{abstract}

\section{Bevezetés}

$\mathrm{Az}$ acélkeretek hagyományos analízise és tervezése során általában azt a feltételezést tesszük, hogy az oszlopokat és gerendákat összekötő csomópontok teljesen merevek, vagy ideálisan csuklósak. A hegesztett kapcsolatok jól közelíthetőek a teljesen merev modell segítségével [2]. Kísérleti megfigyelések alapján azonban kimondhatjuk, hogy a gyakorlatban minden kötés olyan merevséggel rendelkezik, mely a teljesen merev és ideálisan csuklós kötés, mint határérték közé esik. Erre utal a félmerev elnevezés. Ezek a kapcsolatok általában csavarozott kapcsolatok, és fő jellemzőjük a nyomaték-szögelfordulás karakterisztika. Az l.ábra néhány fontos félmerev kötést, és azok nyomaték-szögelfordulás görbéjét mutatja be. Az 1. ábra vízszintes tengelye az ideálisan csuklós kötést feltételező, míg a függőleges tengelye a teljesen merev kötést feltételező esetet szemlélteti.

A vizsgálat során nyomaték-szögelfordulás karakterisztika meghatározását a 2. ábrán látható csomópontra végeztem el. Ez a csomópont a gerenda övlemezein mindkét irányban túlnyúló homloklemezzel van szerelve. A homloklemez a gerendához van hegesztve, az oszlop övlemezéhez pedig hat darab M16-os 8.8-as minőségi osztályú csavarral van rögzítve. Mind az oszlop, mind pedig a gerenda hegesztett I szelvény, a szelvények és a homloklemez pedig egységesen $5 \mathrm{~mm}$-es varratméretekkel rendelkeznek. 


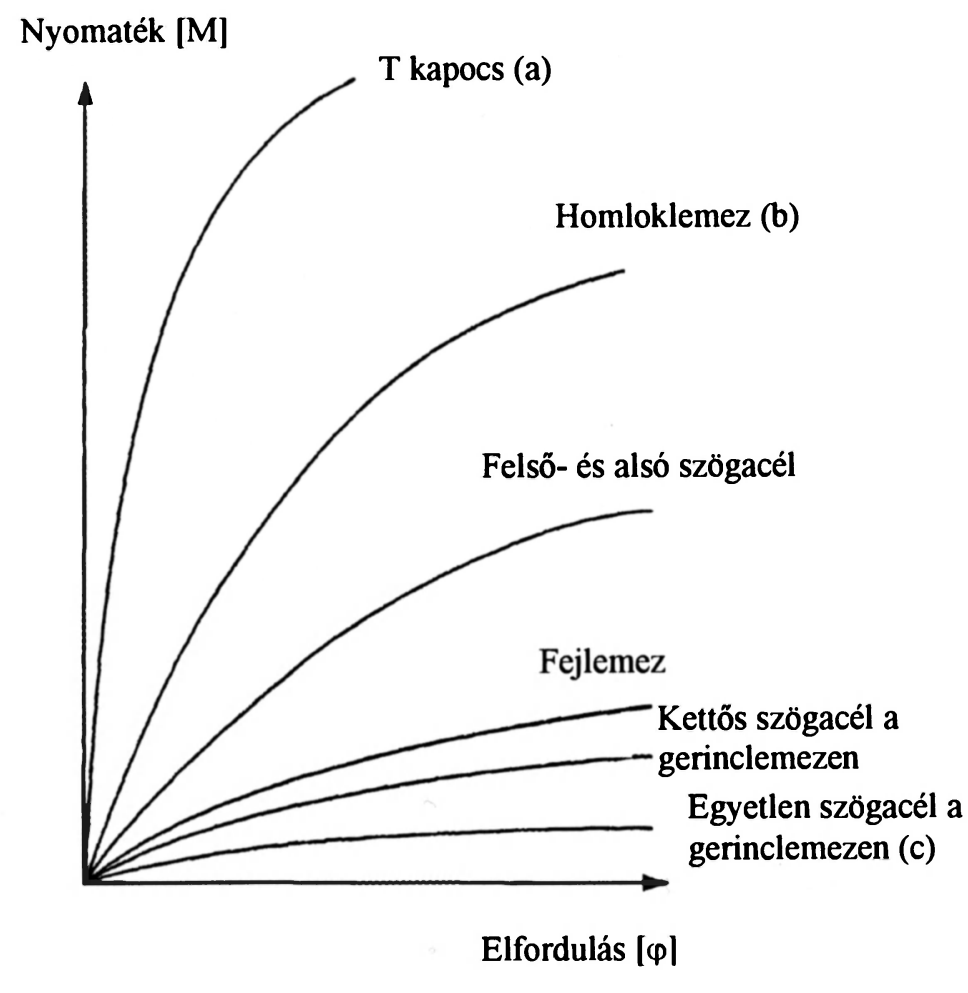

(a)

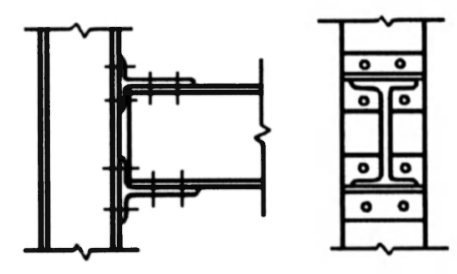

(b)

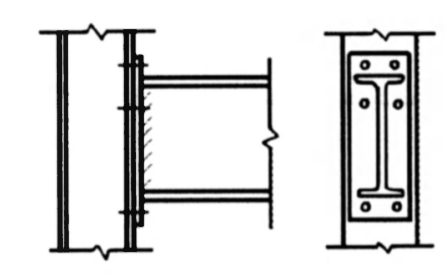

(c)

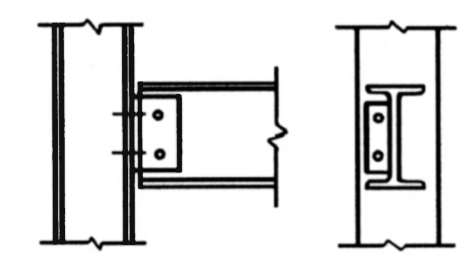

1.ábra
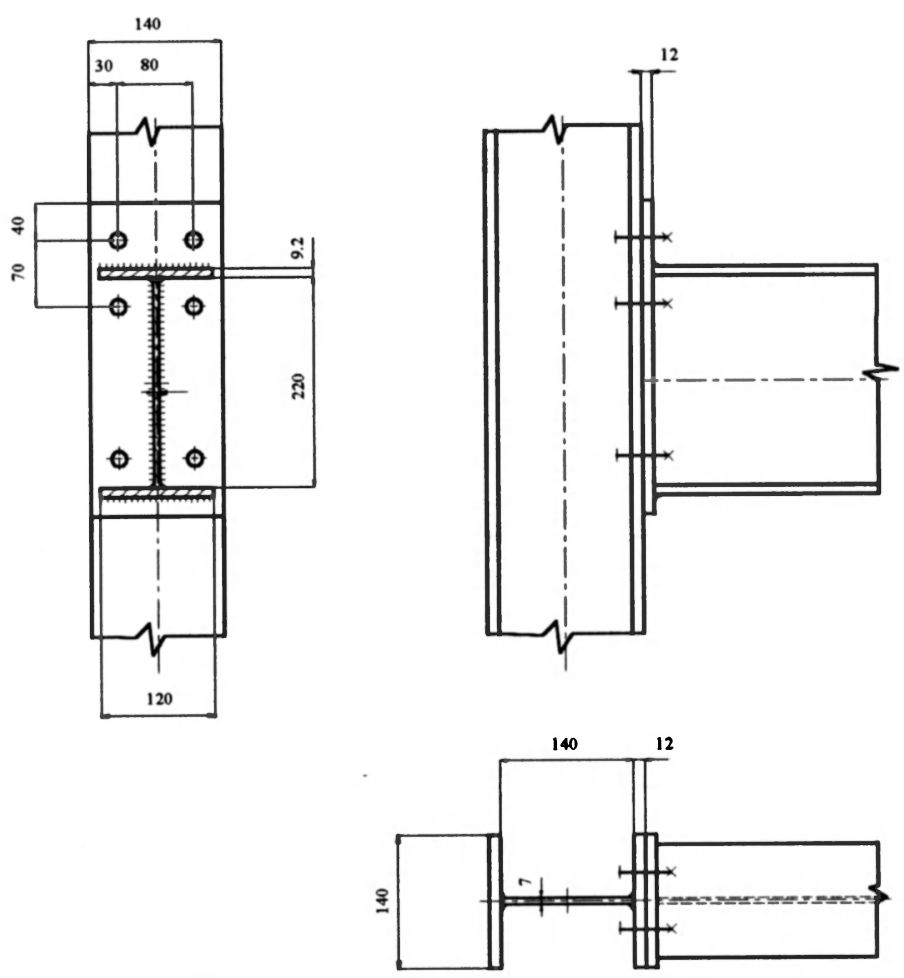

2ábra 


\section{Elfordulási merevség számítása}

A csavarozott oszlop-gerenda kapcsolat elfordulási merevsége a következő módon közelíthető [1]:

$$
S_{j}=\frac{\underline{E h_{1}^{2} t_{w c}}}{\sum\left(\frac{\mu \boldsymbol{t}_{i}}{k_{i}}\left(\frac{F_{i}}{F_{i, R d}}\right)^{2}\right)}
$$

A vizsgálat során a képlet nevezőjét alkotó tagot a csomópont hat különböző zónájára kell kiszámítani, melyek a következők: oszlopgerinc nyírt zónája, oszlopgerinc húzott zónája, oszlopgerinc nyomott zónája, oszlopöv húzott zónája, csavar húzott zónája és a homloklemez húzott zónája. $S_{j}$ tulajdonképpen a kapcsolat $M$ nyomatékához $\left(M \leq M_{R d}\right)$ tartozó húrmerevség, $M_{R d}$ pedig a kapcsolat tervezési nyomatéki ellenállása. $F_{i}$ az $M$ nyomatékból az $i$-edik elemben müködő erő és $F_{i, R d}$ a kapcsolat $i$-edik elemének tervezési ellenállása. $h_{l}$ a gerenda húzott öve alatti első csavarsor távolsága a nyomott zóna ellenállási középpontjától.

\section{A nyomaték-szögelfordulás karakterisztika meghatározása}

Az $S_{j}$ húrmerevséget ki kell számítani a kapcsolat különböző $M$ nyomatékaihoz. Mivel $S_{j}$ az origón és a kiszámítandó ponton átmenő egyenes meredekségét jelenti, ezáltal az adott $M$ nyomatékhoz tartozó szögelfordulás kifejezhető.

\begin{tabular}{|c|c|c|}
\hline$M=M_{R d} / \mathrm{n}[\mathrm{kNm}]$ & $S_{j}[\mathrm{kNm} / \mathrm{rad}]$ & $\varphi=M / S_{j}[1 / 1000 \mathrm{rad}]$ \\
\hline $\mathrm{M}_{\mathrm{Rd}}=27,34$ & 6,193 & 4,415 \\
\hline $\mathrm{M}_{\mathrm{Rd}} / 1,1=24,85$ & 6,522 & 3,811 \\
\hline $\mathrm{M}_{\mathrm{Rd}} / 1,2=22,78$ & 6,796 & 3,352 \\
\hline $\mathrm{M}_{\mathrm{Rd}} / 1,3=21,03$ & 7,027 & 2,993 \\
\hline $\mathrm{M}_{\mathrm{Rd}} / 1,4=19,53$ & 7,221 & 2,704 \\
\hline $\mathrm{M}_{\mathrm{Rd}} / 1,5=18,23$ & 7,385 & 2,468 \\
\hline
\end{tabular}

A kapott pontokat ábrázolva a Curve Expert software segitségével görbét illeszthetünk a pontokhoz, és igy megkaphatjuk a grafikonon látható nyomaték-elfordulás karakterisztikát. 


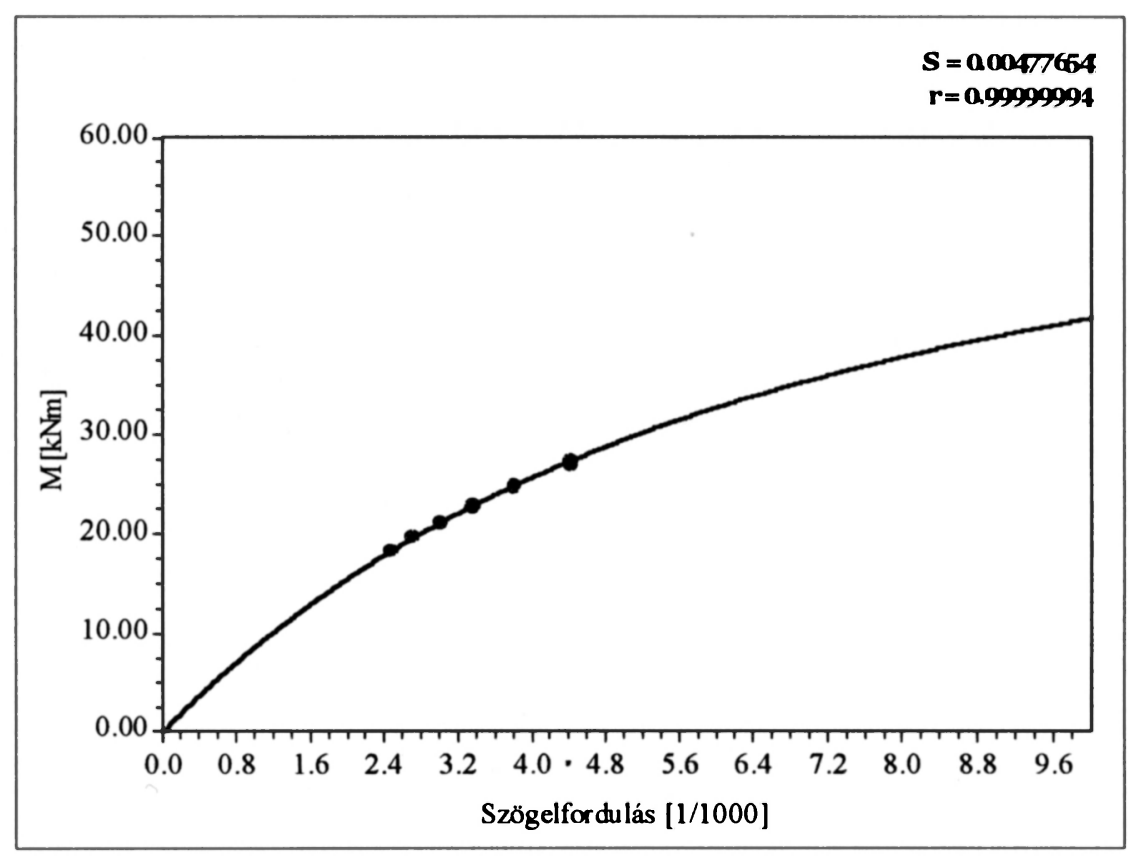

A görbe egyenlete:

$$
\begin{array}{ll}
M=\frac{a+b \varphi}{\mathrm{i}+c \varphi+d \hat{\varphi}^{2}} & \text { A paraméterek értéke: } \\
& \mathrm{a}=-2.7636512 \mathrm{e}-05 \\
& \mathrm{~b}=9.7121637 \\
\mathrm{c}=0.12572045 \\
\mathrm{~d}=0.00068911001
\end{array}
$$

\section{Köszönetnyilvánítás}

A kutatómunka az Országos Tudományos Kutatási Alap OTKA 19003 és OTKA 22846 programok támogatásával készült.

\section{Irodalomjegyzék}

[1] Eurocode 3. "Design of Steel Structures" Part 1.1. Brussels, CEN European Committee for Standardization (1992).

[2] Farkas, J. 'Optimum Design of Metal Structures' 1984. Budapest, Akadémiai Kiadó, Chicester, Ellis Horwood

[3] Farkas, J. and Jármai, K.'Analysis and Optimum Design of Metal Structures' 1997. Rotterdam, Balkema.

Csiky Vidor, okleveles gépészmérnök, doktorandusz Miskolci Egyetem Anyagmozgatási és Logisztikai Tanszék, Miskolc-Egyetemváros (46) 366-111 (20-26) 